paragraph on microseisms together with a table, followed by fifty-three pages in small clear type of the earthqualies recorded. This record contains details of 443 earthquakes, giving in each caso the date, phase and time of recording, the period of the phase, direction of initial impulso and remarks. Tho remarks consist chiefly of amplitudes, epicentre, and readings obtained by other observers who have communicated with De Bilt. A very sound practico has been not to give the recorded time of every prominent pulso but to limit the identifications to $P$, $P P, P P P, S, S S, S S S, L$, and $M$ phases, so presenting very valuable data for seismological research in many directions.

\section{Diploma in Fuel and Refractory Materials at Leeds}

For many years past the University of Leeds has provided courses for post-graduate students leading to special diplomas both in gas engineering and in fuel and metallurgy. A one-year course leading to a post-graduate diploma in fuel and refractory materials has now been arranged, in order to meet the growing demand for men with special training in refractory materials. Commencing in October next, the new course will be given in the Department of Coal Gas and Fuel Industries, and will bo additional to the normal instruction in the subject received by all students reading for degrees in gas engineering and in fuel and metallurgy. An approved degree in science or technology is required as a preliminary qualifica. tion; and the subsequent specialized training in fuel and refractory materials is intended as preparation for entry into either the 'manufacturer' or 'user' sides of the refractories or allied industries. Particulars of these courses may be obtained from the Registrar of the University.

\section{Announcements}

The following awards of the Royal College of Physicians have recently been made: the Moxon Gold Medal to Sir Arthur Hurst, senior physician to Guy's Hospital, for his researches and observations in clinical medicine; the Baly Gold Medal to Prof. C. H. Best, professor of physiology in the University of Toronto, for his physiological researches; the Weber-Parkes Medal and Prize to Sir Pendrill Varrier-Jones, founder and medical director of the Papworth Village Settlement, for his work on tuberculosis at the Settlement.

Tre Council of the City and Guilds of London Institute has conferred the distinction of fellow of the Institute upon the following : Mr. L. B. Atkinson, Mr. C. R. Fairey, Mr. E. Fawssett, Dr. L. F. Goodwin, Sir Follett Holt, Sir Gilbert T. Morgan, Mr. F. Handley Page, Sir Leonard Pearce.

A TEAK memorial seat to the late Sir William Perkin, the chemist, is to be unveiled and dedicated to the public at Sudbury, Middlesex, on August 12. The memorial will be outside a recreation ground, and opposite the site where Sir William's house and laboratory stood. The cost of the memorial has been met by public subseription.
Dr. Givenvron MI. Griffitus has been appointed to the Kathleen Schlesinger research fellowship for the year 1939-40. The fellowship is provided from a fund established by the late Mr. Fugen M. Schlesinger and Mrs. Schlesinger in memory of their daughter, and is given for investigations of cysts of the brain or allied conditions. It is ordinarily tenable at the National Hospital for Diseases of the Nervous System, Queen Square, London.

Prof. Theodor VAhlen, president of the Prussian Academy of Sciences, has been awarded the Goethe Medal for Art and Science by the German Chancellor.

THE Medical Research Council has appointed Dr. Donald Hunter, physician to the London Hospital, and Mr. Harold E. Clay, national secretary of tho Passenger Services Group, Transport and General IVorkers' Union, to bo members of the Industrial Health Research Board, in succession to Prof. J. A. Nixon and Mr. R. Coppock.

Mr. E. J. LudLow of Brylls, Waltham St. Lawrence, Berks, has been awarded the Founders Company fellowship to commence in September next. Mr. Ludlow will be the first person to hold this fellowship, which has been recently created. The normal value of the fellowship is $£ 250$ a year and will be renewable for a second year and in special cases for a third year.

Mr. PaUl Vellacotr, headmaster of Harrow, has been elected master of Peterhouse, Cambridge, in succession to the late Prof. H. W. V. Temperley.

ThE fourth International Congress for Racial Hygiene will be held in Vienna on August 26-28 under the presidency of Prof. E. Rudin. The fee is 10 marks. Further information can be had from the Office of the Congress, Einemstrasse 11, Berlin, WV.62.

IN NATURE of March 25, p. 515, it was stated that the University of Peiping has been reopened under the direction of Prof. Hisomu Nagat, formerly of the University of Formosa. Monlin Chiang, writing as chancellor of the National University of Peking, states that the National University is now in Kunming, Yunnan, as part of the National Southwestern Associated University. He says that, following the fall of the city on July 29, 1937, all the national universities in Peiping moved with their faculties and staffs and almost 90 per cent of their students, leaving behind them practically all their books and apparatus, to the interior and combined into several groups under new names, of which the National Southwestern Associated University is one. As the evacuation took place during the summer vacation, these universities were able to reopen in their new homes more or less according to their original academic calendars, with what little equipment they had secured in the short interval.

Erratua.-In Nature of July 22, p. 150, the dates for the Congress of the International Union against Tuberculosis were incorrectly given as August 11-September 20. They should read September 16-20. 